\title{
Whole Exome Sequencing in Neurogenetic Diagnostic Odysseys: An Argentinian Experience
}

\author{
M Córdoba ${ }^{1}$, SA Rodriguez-Quiroga ${ }^{1}, \mathrm{PA} \mathrm{Vega}^{1}, \mathrm{H} \mathrm{Amartino}^{2}, \mathrm{C}_{\text {Vásquez-Dusefante }}{ }^{1}, \mathrm{~N}$
} Medina $^{1}$, D González-Morón ${ }^{1}$, MA Kauffman ${ }^{1}$

1- Consultorio y Laboratorio de Neurogenética. Hospital JM Ramos Mejía. IBCN Eduardo de Robertis UBA-CONICET, Buenos Aires, Argentina.

2- Servicio de Neurología Infantil. Hospital Universitario Austral, Buenos Aires, Argentina

Corresponding author:

Marcelo Andrés Kauffman

E-mail: marcelokauffman@gmail.com 


\section{ABSTRACT}

Clinical variability is a hallmark of neurogenetic disorders. They involve widespread neurological entities such as neuropathies, ataxias, myopathies, mitochondrial encephalopathies, leukodystrophies, epilepsy and intellectual disabilities. Despite the use of considerable time and resources, the diagnostic yield in this field has been disappointingly low. This etiologic search has been called a "diagnostic odyssey" for many families. Whole exome sequencing (WES) has proved to be useful across a variety of genetic disorders, simplifying the odyssey of many patients and their families and leading to subsequent changes in clinical management in a proportion of them. Although a diagnostic yield of about $30 \%$ in neurogenetic disorders can be extrapolated from the results of large series that have included other medical conditions as well, there are not specific reports assessing its utility in a setting such as ours: a neurogeneticist led academic group serving in a low-income country. Herein, we report on a series of our first 40 consecutive cases that were selected for WES in a research-based neurogenetics laboratory. We demonstrated the clinical utility of WES in our patient cohort, obtaining a diagnostic yield of $40 \%$ (95\% CI, $24.8 \%-55.2 \%)$, describing cases in which clinical management was altered, and suggesting the potential cost-effectiveness of WES as a single test by examining the number and types of tests that were performed prior to WES which added up to a median cost of \$3537.6 (\$2892 to \$5084) for the diagnostic odysseys experienced by our cohort. 


\section{INTRODUCTION}

Clinical variability is a hallmark of neurogenetic disorders. They involve widespread neurological entities such as neuropathies, ataxias, myopathies, mitochondrial encephalopathies, leukodystrophies, epilepsy and intellectual disabilities. Unsurprisingly its diagnostic approach has traditionally been a complex one requiring thorough clinical and familial assessment and the use of several complementary tests such as neuroimages, metabolite and enzyme assays and single-gene analysis. However, despite the use of considerable time and resources, the diagnostic yield in this field has been disappointingly low. This etiologic search has been called a "diagnostic odyssey" (Carmichel et al., 2014) for many families.

Whole exome sequencing (WES) has proved to be useful across a variety of genetic disorders, simplifying the odyssey of many patients and their families and leading to subsequent changes in clinical management in a proportion of them (Johansen Taber, Dickinson \& Wilson, 2014). Although a diagnostic yield of about $30 \%$ in neurogenetic disorders can be extrapolated from the results of large series that have included other medical conditions as well (Fogel et al., 2014; Gillissen et al., 2014; Bettencourt et al., 2014; Mercimek-Mahmutoglu et al., 2015), there are not specific reports assessing its utility in a setting such as ours: a neurogeneticist led academic group serving in a low-income country. Herein, we report on a series of our first 40 consecutive cases that were selected for WES in a research-based neurogenetics laboratory. We demonstrate the clinical utility of WES in our patient cohort, calculating the diagnostic yield, detailing the cases in which clinical management was altered, and potential cost-effectiveness of WES as a single test by examining the number and types of tests that were performed prior to WES that add to the cost of diagnostic workups. 


\section{MATERIAL \& METHODS}

\section{Clinical samples}

We included a consecutive series of 40 patients selected for WES from a Neurogenetic Clinic of a tertiary Hospital in Argentina. These patients were considered candidates for genomic studies according to the presence of typical findings of known neurogenetic diseases and/or hints of monogenic etiology such as familial aggregation or chronic and progressive course. We recorded perinatal and familial history, likely inheritance model/s, disease progression characteristics, comorbidities and studies performed before WES from each patient of our cohort. The diverse clinical features of this cohort are summarized in Table 1. Consent for WES was obtained from the patients and/or their family. Internal review board (IRB) approval was obtained at Hospital JM Ramos Mejia.

TABLE 1. Patient demographic information and description of clinical presentation

\begin{tabular}{|c|c|c|c|c|}
\hline $\begin{array}{l}\text { CASE } \\
\text { ID }\end{array}$ & $\begin{array}{l}\text { AGE OF } \\
\text { ONSET }\end{array}$ & $\begin{array}{l}\text { AGE AT } \\
\text { TESTING }\end{array}$ & PRIMARY DISEASE CLASSIFICATION & CLINICAL PRESENTATION \\
\hline 1 & 1 & 28 & - & $\begin{array}{c}\text { Mental retardation, autism, epilepsy, } \\
\text { dystonia }\end{array}$ \\
\hline 2 & 5 & 9 & Epilepsy with Variable Foci & Epilepsy \\
\hline 3 & 1 & 5 & Dravet Syndrome & Epilepsy, cognitive impairment \\
\hline 4 & 9 & 17 & Hemiplegic Migraine & Episodic migraine, hemiplegia \\
\hline 5 & 14 & 24 & Sporadic ataxia & $\begin{array}{l}\text { Ataxia, myoclonus, cognitive impairment, } \\
\text { cerebellar atrophy on MRI }\end{array}$ \\
\hline 6 & 9 & 24 & Spastic Paraplegia Plus & $\begin{array}{l}\text { Paraparesis, mental retardation, thinning } \\
\text { of the corpus callosum on MRI, peripheral } \\
\text { neuropathy }\end{array}$ \\
\hline 7 & 4 & 23 & - & $\begin{array}{c}\text { Generalized dystonia, chorea, cognitive } \\
\text { impairment }\end{array}$ \\
\hline 8 & 2 & 5 & Epileptic encephalopathy & $\begin{array}{l}\text { Ataxia, absence epilepsy, } \\
\text { neurodevelopmental delay }\end{array}$ \\
\hline 9 & 8 & 50 & Myopathy & $\begin{array}{l}\text { Very mild muscle weakness, } \\
\text { hyperCKemia }\end{array}$ \\
\hline 10 & 1 & 11 & Epileptic encephalopathy & Autism, hyperactivity, epilepsy \\
\hline 11 & 6 & 11 & Ataxia + oculomotor apraxia & $\begin{array}{c}\text { Ataxia, chorea, tremor, oculomotor } \\
\text { apraxia }\end{array}$ \\
\hline 12 & 16 & 23 & Leukodystrophy & $\begin{array}{c}\text { On MRIs leukodystrophy + cognitive } \\
\text { impairment Ataxia + pyramidal syndrome } \\
+ \text { abnormal eye movements }\end{array}$ \\
\hline 13 & 55 & 70 & Sporadic ataxia & Ataxia \\
\hline 14 & 1 & 4 & Leigh syndrome & $\begin{array}{c}\text { Developmental delay, refractory epileptic } \\
\text { encephalopathy, hypointense on } \mathrm{T} 1, \mathrm{~T} 2 \\
\text { hyper intensity in the basal ganglia } \\
\text { positive spread }\end{array}$ \\
\hline 15 & 11 & 22 & Mitochondrial & Muscle fatigue \\
\hline 16 & 1 & 5 & Chain respiratory disorder & Developmental delay, recurrent vomiting \\
\hline 17 & 29 & 54 & Sporadic ataxia & Ataxia, pyramidal. \\
\hline 18 & 5 & 15 & Ataxia & Ataxia, neuropathy, cerebellar atrophy \\
\hline 19 & 2 & 12 & - & Developmental Disorder, speech \\
\hline
\end{tabular}




\begin{tabular}{|c|c|c|c|c|}
\hline & & & & impairment, polyneuropathy \\
\hline 20 & 42 & 53 & Sporadic ataxia & Ataxia, cerebellar atrophy \\
\hline 21 & 3 & 11 & Epileptic encephalopathy & Partial seizures, ataxia \\
\hline 22 & Neonatal & 3 & Neonatal adrenoleukodystrophy & $\begin{array}{c}\text { Hepatic dysfunction, hypotonia, white } \\
\text { matter lesions on MRI }\end{array}$ \\
\hline 23 & Neonatal & 3 & Encephalopathy & $\begin{array}{l}\text { Mental delay, physical growth retardation, } \\
\text { diarrhea, vomiting and increased lactic } \\
\text { acid }\end{array}$ \\
\hline 24 & Neonatal & 9 & Encephalopathy & $\begin{array}{c}\text { Developmental delay, seizures, muscular } \\
\text { weakness, dystonia. Fragmentary hypo } \\
\text { myelination on MRI }\end{array}$ \\
\hline 25 & 30 & 52 & Episodic ataxia & Episodic ataxia \\
\hline 26 & 12 & 23 & Leukodystrophy & $\begin{array}{c}\text { Ataxia, cognitive impairment, abnormal } \\
\text { ocular movements. Symmetric hypo } \\
\text { myelination on MRI }\end{array}$ \\
\hline 27 & 27 & 33 & Rhabdomyolysis & Rhabdomyolisis, muscular fatigue \\
\hline 28 & $6 \mathrm{~m}$ & 5 & Mitochondrial & $\begin{array}{l}\text { Developmental delay, epilepsy, dystonia, } \\
\text { ragged red fibers on muscular biopsy }\end{array}$ \\
\hline 29 & 3 & 32 & Myopathy & $\begin{array}{c}\text { Proximal muscular weakness, muscular } \\
\text { atrophy }\end{array}$ \\
\hline 30 & Neonatal & 8 & Glycosylation congenital disorder & $\begin{array}{c}\text { Microcephaly, seizures, muscular } \\
\text { weakness }\end{array}$ \\
\hline 31 & Neonatal & 10 & Polymicrogyria & Seizures, polymicrogyria on MRI \\
\hline 32 & 2 & 8 & - & Speech impairment, developmental delay \\
\hline 33 & $18 \mathrm{~m}$ & 31 & Spastic quadriplegia & $\begin{array}{l}\text { Quadriplegia, pyramidal dysfunction, } \\
\text { fasciculation, muscular atrophy }\end{array}$ \\
\hline 34 & 50 & 58 & Ataxia / Dementia & $\begin{array}{c}\text { Progressive multidomain cognitive } \\
\text { impairment, ataxia }\end{array}$ \\
\hline 35 & $6 \mathrm{~m}$ & 5 & Myopathy & $\begin{array}{c}\text { Developmental delay, hypotonia, muscular } \\
\text { weakness }\end{array}$ \\
\hline 36 & 8 & 19 & Dystonia & Generalized dystonia \\
\hline 37 & 2 & 16 & Optic Neuropathy & Progressive visual loss \\
\hline 38 & 41 & 53 & Sensory Ataxia & Ataxia, distal hypoesthesia \\
\hline 39 & 6 & 17 & NBIA & Dystonia, tremor \\
\hline 40 & 46 & 56 & Sub acute Dementia-Movement Disorders & Behavioral disorders, tremor, bradykinesia \\
\hline
\end{tabular}

*36 were patients with a defined clinical syndrome and underwent trough targeted molecular hypothesis, with a first filter with known gene panels.

\#The rest represents complex phenotypes with other neurological features.

The mean age for exome analysis was 30 , between 3 and 70 years. (Age at testing column)

The mean time between the beginning of the disease and the exome analysis was $11.5,3$ and 42 years range. (Difference between age of onset and age at testing column)

\section{Whole Exome Sequencing and Sanger confirmation}

Genomic DNA was isolated from blood samples of each subject with the use of commercial kits. DNA sequencing libraries were constructed mostly by chemical fragmentation using commercial preparation kits. Exomes were enriched using different systems, being the vast majority of our cases processed with SureSelect Human All Exon v4 Kits (Agilent Technologies, Santa Clara, CA, USA). NGS sequencing runs were made in Illumina HiSeq 2500 systems as an outsourced service from Macrogen Inc (Korea) obtaining an average sequence coverage of more than $70 \mathrm{X}$, with more than $97 \%$ of the target bases having at least 10X coverage. All standardized procedures were performed according to manufacturers 
instructions that have been widely mentioned in the literature (Kosarewa \& Turner, 2011; Margraf et al., 2011). Clinically relevant variants, from proband and parental samples (whenever available), were confirmed by Sanger sequencing.

\section{Data analysis and annotation}

Sequence data in FastQ format were aligned to the human reference genome (GRCh37) using the Burrows-Wheeler Alignment Tool (BWA-MEM) (Heng 2013). Variants Calls were generated using GATK haplotype caller following the so called best practices (Geraldine et al., 2013). The output vef file was annotated at various levels using Annovar (Wang, Li \& Hakonarson, 2010) (Figure 1 A) Variants were prioritized according to inheritance model, population frequency, potential impact at molecular level, reported clinical effect, and optionally according to a list of genes associated with the disease under study. In that sense two in house protocols were defined. One "molecular hypothesis free", for patients presenting complex phenotypes without candidate genes. Other "molecular hypothesis targeted" for patients that shows a defined clinical syndrome with available candidate genes. (Figure $1 \mathrm{~B}$ ). Classification of candidate gene alterations followed previously published schemes (Richards et al., 2008) updated with recent recommendations and guidelines by the American College of Medical Genetics and Genomics and the Association for Molecular Pathology. (Richards et al., 2015) Joining variant level and clinical features information, we classified each WES study as positive if a pathogenic/likely pathogenic mutation in known disease gene was identified with positive phenotypic and inheritance overlap; undetermined if a pathogenic/likely pathogenic mutation in a putative candidate gene was identified with positive phenotypic and inheritance overlap or only one pathogenic/likely pathogenic mutation was identified with positive phenotypic overlap in a recessive disorder and negative in the rest of the cases. 
bioRxiv preprint doi: https://doi.org/10.1101/060319; this version posted June 23, 2016. The copyright holder for this preprint (which was

not certified by peer review) is the author/funder, who has granted bioRxiv a license to display the preprint in perpetuity. It is made available under aCC-BY-NC-ND 4.0 International license.

\section{FIGURA 1}

A

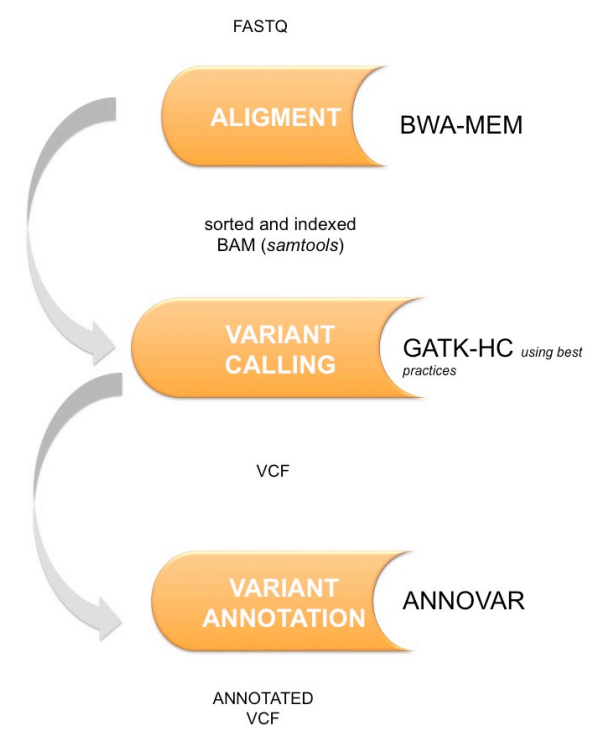

B

MOLECULAR HYPOTESIS FREE PROTOCOL
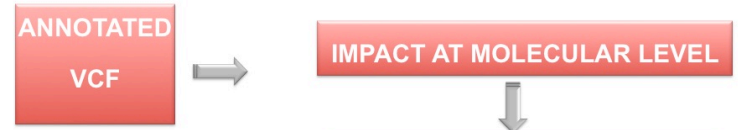

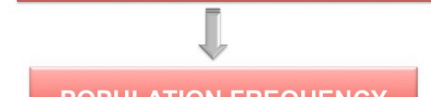

POPULATION FREQUENCY

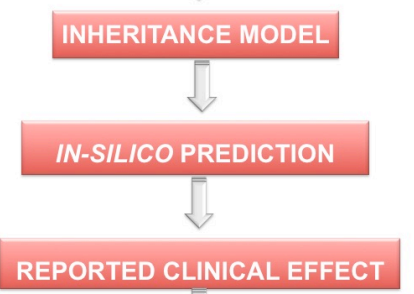

PRIORITIZED GENES LIST
MOLECULAR HYPOTESIS TARGETED PROTOCOL

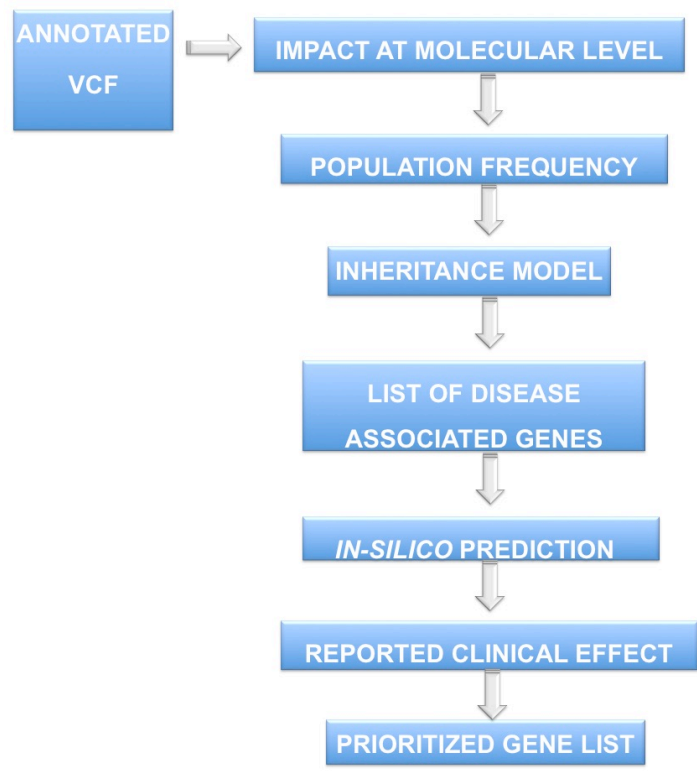

Figure $1 \mathrm{~A}$ shows the workflow for annotated vcf obtention: Sequence alignment using the Burrows-Wheeler Alignment Tool (BWA-MEM) (Heng 2013); variants calling by GATK haplotype caller (Geraldine et al., 2013). The output vef file was annotated at various levels using Annovar (Wang, Li \& Hakonarson, 2010)

Figure $1 \mathrm{~B}$ summarizes prioritization strategies according to molecular hypothesis free and molecular hypothesis targeted schemas

\section{RESULTS}

\section{Cohort Description}

The majority of our patients (36) could be classified in well-defined neurological categories of diseases; the remaining four were complex phenotypes. (Figure 2, Cohort). Intellectual 
disability and neurodevelopmental delay were present in $45 \%$ of our patients. Ataxia, Epilepsy and Movement Disorders were other common symptoms, being present in $22 \%$, $20 \%$ and $10 \%$, respectively. Other prominent features that led to WES in our cohort were a suspicion of mitochondrial disorders (7.5\%) and MRI white matter abnormalities defining a leukoencephalopathy (7.5\%) (Table 1). Parental consanguinity was reported in $1(2,5 \%)$ proband. The average age at the time of WES was 23 (3-70). The mean time elapsed from symptom onset to WES was 11 years (range 3-42).

\section{FIGURA 2}

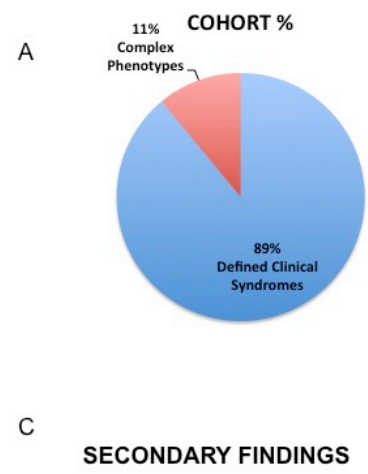

Choices of receiving incidental findings
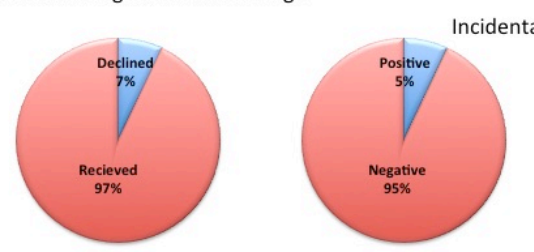

B

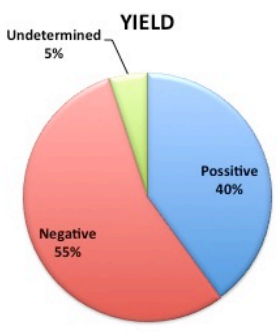

DIAGNOSTIC ODISSEY
PREVIOUS GENETIC TESTS

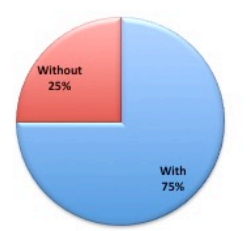

PATIENTS WITH $>2$ MRI

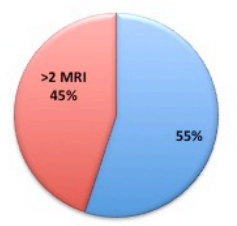

Figure 2 summarizes A) cohort characteristics according to phenotype presentation, B) diagnostic yield, C) incidental findings and the D) so called diagnostic odissey describing proportion of patients with previous genetic test and patients with 2 or more MRIs.

\section{Exome Sequencing}

Exome sequencing produced an average of $8 \mathrm{~GB}$ of sequence per sample. Mean coverage of targeted regions was greater than $70 \mathrm{X}$ per sample, with $96,2 \%$ covered at least $10 \mathrm{X}$. Average Illumina Q score was higher than 30 in more than $90 \%$ of bases. Variant calling resulted in about 75000 variants per sample, whereas about five were prioritized as potential clinically 
useful after variant and phenotypic filters where applied. All of them were confirmed as true positives when Sanger sequencing was done.

\section{WES Diagnostic Yield}

Sixteen WES satisfied criteria for a full molecular diagnosis (Table 2), thus the overall diagnostic yield for WES in our series was 40\% (Figure 2, Yield). Among them, two WES were reclassified from original undetermined and negative categories after subsequent reanalysis identified pathogenic variants in genes not associated with human disorders at the time of original reports (see below). A diverse group of neurological disorders were represented in the positive patients (Table 2), including neurodevelopmental disorders, epileptic encephalopathies, ataxias, leukoencephalopaties and neuromuscular diseases. Although almost all of the molecular diagnoses were in nuclear genes, mitochondrial genome sequencing included in the WES test, yielded one diagnosis (one individual with a missense mutation in MT-T8893G). The positive group included 9 patients with autosomal dominant disease and 7 with autosomal recessive disease. Different mutation types were observed in this cohort: 3 frameshift, 3 nonsense, 12 missense mutations, 1 nonframeshift, 2 splicing (Table 2). Noteworthy, $56 \%$ of the mutations were novel.

Two WES were defined as undetermined (5\%). In one of then we were able to identified only one pathogenic variant (c.1568T $>$ A;p.Val523Glu) in POLR3B in a patient showing clinical features consistent with autosomal recessive POLR3-related disorders (Wolf et al. 2014). We hypothesize that the second missing allele is a large deletion/insertion or a deep intronic mutation. This case highlight current limitation of WES. In case 17 we found a heterozygous likely pathogenic variant (c.C668A;ProA223Asp) in RNF170 gene. This gene was reported as cause of sensory ataxia. The patient phenotype corresponds to pure cerebellar ataxia. (Wright et al. 205) 
bioRxiv preprint doi: https://doi.org/10.1101/060319; this version posted June 23, 2016. The copyright holder for this preprint (which was

not certified by peer review) is the author/funder, who has granted bioRxiv a license to display the preprint in perpetuity. It is made available under aCC-BY-NC-ND 4.0 International license.

TABLE 2. Exomes with definitive diagnosis

\begin{tabular}{|c|c|c|c|c|c|c|c|}
\hline $\begin{array}{l}\text { CASE } \\
\text { ID }\end{array}$ & GENE & OMIM & INHERITANCE & MUTATION(S) & LITERATURE & $\begin{array}{c}\text { TYPE OF } \\
\text { MUTATION }\end{array}$ & $\begin{array}{c}\text { ALTERED } \\
\text { MANAGEMENT }\end{array}$ \\
\hline 1 & GRIK2 & 611092 & Reccesive & $\begin{array}{l}\text { NM_021956.4:c592 } \\
\text { C>T; p.Arg198ter }\end{array}$ & $\begin{array}{l}\text { (Motazacker MM } \\
\text { et al. 2007) }\end{array}$ & nonsense & $\begin{array}{l}\text { 1) End diagnostic odyssey, } \\
\text { 2) Informative genetic } \\
\text { counseling }\end{array}$ \\
\hline 2 & DEPDC5 & 604364 & Dominant & $\begin{array}{c}\text { NM_001242896:c.47 } \\
\text { 18T>C;p.Leu1573Pr } \\
\text { o }\end{array}$ & $\begin{array}{c}\text { (Baulac et al. } \\
\text { 2014) }\end{array}$ & missense & $\begin{array}{l}\text { 1) End diagnostic odyssey, } \\
\text { 2) Informative genetic } \\
\text { counseling }\end{array}$ \\
\hline 4 & CACNA1A & 141500 & Sporadic & $\begin{array}{l}\text { NM_000068: } \\
\text { c.3675C }>\text { A; } \\
\text { p.Phe1225Leu }\end{array}$ & (Riant et al. 2010) & missense & $\begin{array}{l}\text { 1) End diagnostic odyssey, } \\
\text { 2) Informative genetic } \\
\text { counseling }\end{array}$ \\
\hline 5 & STUB1 & 607207 & Sporadic & $\begin{array}{c}\mathrm{NM}_{-} 005861.2: \mathrm{c} .612 \\
+1 \mathrm{G}>\mathrm{C} ; \mathrm{p} . ? \\
\mathrm{NM} \text { _005861.2:c.823 } \\
\text { C }>\text { G;Leu } 275 \mathrm{Val}\end{array}$ & (Shi et al. 2014) & splicing/missense & $\begin{array}{l}\text { 1) End diagnostic odyssey, } \\
\text { 2) Informative genetic } \\
\text { counseling } \\
\text { 3) Start regular endocrine } \\
\text { evaluation to monitor } \\
\text { potential } \\
\text { hypogonadotrophism }\end{array}$ \\
\hline 6 & SPG11 & 604360 & Sporadic & $\begin{array}{c}\text { NM_025137:c.6763i } \\
\text { nsA;p.Gln2242His } \\
\text { NM_025137:6726A> } \\
\text { T;p.Leu2255HisfsX8 } \\
\text { 3; } \\
\end{array}$ & $\begin{array}{c}\text { (Stevanin et al. } \\
\text { 2007) }\end{array}$ & $\begin{array}{l}\text { frameshift } \\
\text { missense }\end{array}$ & $\begin{array}{l}\text { 1) End diagnostic odyssey, } \\
\text { 2) Informative genetic } \\
\text { counseling }\end{array}$ \\
\hline 8 & KCNA2 & 616366 & Sporadic & $\begin{array}{l}\text { NM_001204269::c.G } \\
\text { 890A:p.Arg297Glu }\end{array}$ & (Syrbe et al. 2015) & missense & $\begin{array}{l}\text { 1) End diagnostic odyssey, } \\
\text { 2) Informative genetic } \\
\text { counseling } \\
\text { 3)Empirical treatment with } \\
\text { acetazolamide }\end{array}$ \\
\hline 9 & DMD & 300377 & Sporadic & $\begin{array}{c}\mathrm{NM}_{-004006.2: \mathrm{c} .114} \\
9+1 \mathrm{C}>\mathrm{A}\end{array}$ & $\begin{array}{l}\text { (Carsana et al. } \\
\text { 2010) }\end{array}$ & splicing & No \\
\hline 11 & APTX & 208920 & Reccesive & $\begin{array}{c}\text { NM_175069.1:c.879 } \\
\text { G>A; p.Trp293ter }\end{array}$ & $\begin{array}{c}\text { (Shimazaki et al. } \\
\text { 2002) }\end{array}$ & nonsense & $\begin{array}{l}\text { 1) End diagnostic odyssey, } \\
\text { 2) Informative genetic } \\
\text { counseling }\end{array}$ \\
\hline 21 & PCDH19 & 300088 & Sporadic & $\begin{array}{l}\text { NM_001184880:exo } \\
\text { n1:c.T1151G:p.Val3 } \\
\text { 84Gly }\end{array}$ & $\begin{array}{c}\text { (Hynes et al. } \\
\text { 2010) }\end{array}$ & nonsense & $\begin{array}{l}\text { 1) End diagnostic odyssey, } \\
\text { 2) Informative genetic } \\
\text { counseling }\end{array}$ \\
\hline 22 & PEX12 & 266510 & Sporadic & $\begin{array}{r}\text { NM_000286:c.733_7 } \\
\text { 34insGCCT:p.Leu } 24 \\
\text { 5fs } \\
\text { NM_000286:c.533_5 } \\
\text { 35del:p.178_179del }\end{array}$ & $\begin{array}{l}\text { (Gootjes et al. } \\
2004)\end{array}$ & $\begin{array}{c}\text { frameshift } \\
\text { nonframeshift }\end{array}$ & $\begin{array}{l}\text { 1) End diagnostic odyssey, } \\
\text { 2) Informative genetic } \\
\text { counseling }\end{array}$ \\
\hline 26 & POLR3A & 607694 & Recessive & $\begin{array}{c}\text { NM_007055.3:c.378 } \\
\text { 1G>A; } \\
\text { p.Glu1261Lys } \\
\text { NM_007055.3:c.301 } \\
\text { 4G }>\text { A;p.Arg1005His }\end{array}$ & (Wolf et al. 2014) & $\begin{array}{l}\text { missense } \\
\text { missense }\end{array}$ & $\begin{array}{l}\text { 1) End diagnostic odyssey, } \\
\text { 2) Informative genetic } \\
\text { counseling }\end{array}$ \\
\hline 28 & $\begin{array}{l}\text { Mitochondria } \\
1 \text { Genome }\end{array}$ & 551500 & Mitochondrial & m.T8893G & (Holt et al. 1990) & missense & $\begin{array}{l}\text { 1) End diagnostic odyssey, } \\
\text { 2) Informative genetic } \\
\text { counseling } \\
\text { 3) Avoid side effects of } \\
\text { certain drug/agents, }\end{array}$ \\
\hline 29 & SGCG & 608896 & Sporadic & $\begin{array}{c}\text { NM_000231:exon6:c } \\
\text {.521delT:p.Phe175Le } \\
\text { ufsX20 } \\
\end{array}$ & (Lasa et al. 1998) & frameshift & 1) End diagnostic odyssey \\
\hline 30 & GNAO1 & 615473 & Sporadic & $\begin{array}{c}\text { NM_020988:c.709G } \\
>\text { >A:p.Glu237Lys }\end{array}$ & $\begin{array}{c}\text { (Nakamura et al. } \\
\text { 2013) }\end{array}$ & missense & No \\
\hline 33 & ALS2 & 607225 & Sporadic & $\begin{array}{l}\text { NM_020919:exon13: } \\
\text { c.T2531A:p.Leu844 } \\
\text { His }\end{array}$ & $\begin{array}{l}\text { (Eymard-Pierre et } \\
\text { al. 2006) }\end{array}$ & missense & $\begin{array}{l}\text { 1) End diagnostic odyssey, } \\
\text { 2) Informative genetic } \\
\text { counseling }\end{array}$ \\
\hline 40 & ATP7B & 277900 & Reccesive & $\begin{array}{l}\text { NM_000053:c.2165T } \\
\text { >A:p.Leu722Gln } \\
\text { NM_000053:c.3704 } \\
\text { G>A.p.Gly235Asp }\end{array}$ & $\begin{array}{c}\text { (Takeshita et al. } \\
\text { 2002) }\end{array}$ & $\begin{array}{l}\text { missense } \\
\text { missense }\end{array}$ & $\begin{array}{l}\text { 1) End diagnostic odyssey, } \\
\text { 2) Informative genetic } \\
\text { counseling } \\
\text { 3)Treatment with } \\
\text { Penicilamine }\end{array}$ \\
\hline
\end{tabular}

\section{Impact of diagnosis in medical management}

Table 2 shows a summary of the impact that a definitive diagnosis obtained from WES had in our patients. In terms of medical management, the usefulness of WES can be defined in a 
broad sense, that includes the possibility to return timely results, subspecialty consultant, medication or diet changes, palliative care initiation and, last but not less important, the ending of diagnostic odyssey. (Carmichel et al., 2014)

For example, patient 8, a 5- year-old girl with neurodevelopmental delay, ataxia and epilepsy since the age of 2. Exome sequencing was performed in the beginning of 2013 without any significant result. In September 2015, this sample was reanalysed and we found a pathogenic variant in KCN2A gene. This mutation was reported in April 2015 (Syrbe et al., 2015) as a cause of epileptic encephalopathy in a patient showing a similar phenotype. KCN2A encodes a voltage-gate potassium channel, classically studied in Dosophila (Pongs et al., 1988) and ataxia mice models (Xie et al. 2010). The mutation identified results in a key amino acid substitution at the voltage sensor domain S4 leading to a gain of function in channel activity. The information obtained by means of WES in this case ended the diagnostic odyssey for this family and opens the possibility to assess the efficacy of drugs with action in KCNA2 channels such as acetazolamide or fampridine.

In our cohort, three subjects declined to receive incidental findings. (Figure 2, Incidental Findings). In the remaining 37 patients, we found two variants in medically actionable genes as defined by ACMG recommendations (Richards et al., 2015). Patient 11 carried a probable pathogenic variant in BRCA1 gene. Thus, we counselled her and her relatives to have a consultation with their general practitioner in order to discuss periodic surveillance for breast and ovarian cancer. In patient 28 , we found a variant of the RYR1 gene, which could increase the risk for developing malignant hyperthermia episodes after exposure to anesthetics. We suggested to disclose this information in the case of being exposed to surgical procedures.

\section{Odyssey numbers}


As an exploratory approach to a monetary cost-analysis of WES in neurogenetics diseases, we recorded the number and type of complementary tests done by our patients before WES. Table 3 shows that several genetic and non-genetic assays were performed in all of our patients. The mean average cost of the diagnostic workup prior to WES was $\$ 3537.6$ (\$2892 to $\$ 5084)$. At least one genetic test was done in 10 patients; five of them had four different assays performed. Therefore, for these five patients the cost of genetic testing before WES can be considered significant and greater than WES. We also observed the frequent repetition of complementary studies. For instance, three MRI had been performed in the diagnostic workup prior WES in 12 patients. This often-unnecessary repetition of neuroimages might be a consequence of the extension in time of the so-called diagnostic odyssey. (Figure 2, Diagnostic Odyssey).

Table 3. Tests and Exams prior to Whole Exome Sequencing

\begin{tabular}{|c|c|c|c|c|c|c|c|c|c|c|}
\hline Case id & $\begin{array}{l}\mathrm{CT} \\
\end{array}$ & MRI & EMG & $\begin{array}{c}\text { Biochemical } \\
\text { genetics }\end{array}$ & $\begin{array}{c}\text { Muscle } \\
\text { biopsies }\end{array}$ & CSF & $\begin{array}{c}\text { Sanger } \\
\text { sequencing/MLPA }\end{array}$ & $\begin{array}{l}\text { Total number } \\
\text { of previous } \\
\text { studies }\end{array}$ & $\begin{array}{c}\text { Number of } \\
\text { specialized } \\
\text { outpatients visits }\end{array}$ & $\begin{array}{c}\text { Total } \\
\text { estimated } \\
\text { cost \$ }\end{array}$ \\
\hline 1 & 1 & 3 & 1 & 1 & & 1 & & 7 & 8 & 3950 \\
\hline 2 & 1 & 1 & & 1 & & & & 3 & 7 & 2942 \\
\hline 3 & & 2 & & 1 & & & & 3 & 6 & 3014 \\
\hline 4 & & 3 & & & & & & 3 & 9 & 3171 \\
\hline 5 & 1 & 3 & 2 & 1 & & & 4 & 11 & 7 & 5084 \\
\hline 6 & & 2 & 2 & 1 & & 1 & & 6 & 8 & 3522 \\
\hline 7 & 1 & 3 & & 1 & & 1 & & 5 & 5 & 3536 \\
\hline 8 & & 2 & 1 & 1 & & 1 & & 5 & 7 & 3194 \\
\hline 9 & & 1 & 2 & & 1 & & & 4 & 9 & 3178 \\
\hline 10 & & 2 & & 1 & & 1 & & 4 & 11 & 3594 \\
\hline 11 & & 2 & 1 & 1 & & 1 & 1 & 6 & 7 & 2994 \\
\hline 12 & 1 & 3 & 2 & 1 & & 1 & & 8 & 9 & 3154 \\
\hline 13 & 1 & 2 & 1 & 1 & & 1 & 4 & 10 & 8 & 4783 \\
\hline 14 & & 2 & 1 & 1 & & & & 4 & 7 & 3228 \\
\hline 15 & & 1 & 2 & 1 & 1 & & & 5 & 6 & 3492 \\
\hline 16 & & 1 & 1 & 1 & 1 & & & 4 & 7 & 3478 \\
\hline 17 & & 3 & & 1 & & & 4 & 8 & 9 & 4871 \\
\hline 18 & & 3 & 1 & 1 & & & 4 & 9 & 8 & 4485 \\
\hline 19 & & 2 & 1 & 1 & & 1 & & 5 & 6 & 3208 \\
\hline 20 & & 3 & & 1 & & & 4 & 8 & 5 & 3471 \\
\hline 21 & & 2 & & 1 & & 1 & & 4 & 7 & 3194 \\
\hline 22 & & 3 & & 1 & & & 1 & 5 & 9 & 3971 \\
\hline 23 & & 1 & & 1 & 1 & & & 3 & 8 & 3464 \\
\hline 24 & & 1 & & 1 & 1 & & & 3 & 7 & 3364 \\
\hline 25 & 1 & 2 & & 1 & & & & 4 & 8 & 3399 \\
\hline 26 & & 2 & & 1 & & & & 4 & 9 & 3314 \\
\hline 27 & & & 3 & 1 & 1 & & & 5 & 10 & 3421 \\
\hline 28 & & 1 & 1 & 1 & 1 & & & 4 & 9 & 3678 \\
\hline 29 & & 1 & 3 & 1 & 2 & & 1 & 8 & 6 & 3513 \\
\hline 30 & & 2 & 1 & 1 & 1 & & 1 & 6 & 9 & 3335 \\
\hline 31 & & 2 & & 1 & & & & 3 & 7 & 3114 \\
\hline
\end{tabular}




\begin{tabular}{|c|c|c|c|c|c|c|c|c|c|c|}
\hline 32 & 1 & 2 & & 1 & & 1 & & 5 & 10 & 3679 \\
\hline 33 & & 3 & 4 & 1 & & & 1 & 9 & 9 & 4199 \\
\hline 34 & & 2 & & 1 & & & & 3 & 7 & 3114 \\
\hline 35 & & 1 & 2 & & 1 & & & 4 & 5 & 2892 \\
\hline 36 & & 2 & & 1 & & & & 3 & 7 & 3114 \\
\hline 37 & & 2 & & 1 & & & & 3 & 9 & 3314 \\
\hline 38 & & 3 & 2 & 1 & & 1 & & 7 & 7 & 3779 \\
\hline 39 & 2 & 2 & & 1 & & & & 5 & 6 & 3384 \\
\hline 40 & 1 & 3 & & 1 & & $\overline{2}$ & & 7 & 8 & 3916 \\
\hline
\end{tabular}

\section{DISCUSSION}

Applying WES to a representative sample of 40 patients suffering from neurogenetic diseases, we observed an etiologic diagnostic yield of $40 \%$. A positive diagnosis, putting an ending to the so called diagnostic odyssey of these families, could be offered to sixteen subjects. Furthermore, we were able to expand the phenotypic spectrum of known genes and identify new pathogenic variants in other genes. Our preliminary cost-analysis lend support to the asseveration made by others that WES is more cost-effective than other molecular diagnostic approaches based on single- or panel- gene analysis (Valencia et al. 2015; Monroe et al. 2015). Moreover, there are other diagnostic odysseys costs, that are harder to represent in monetary terms but not less important, such as time lost to the patient/family and quality of life decrement because of this loss. They deserve other type of formal economic studies that could even show more advantages for the use of WES in the diagnostic approach of complex diseases such as neurogenetic disorders.

There are several reports in the literature showing WES as an efficient diagnostic test for monogenic disorders. The diagnostic yield in less restrictive adult and pediatric populations series ranged from 17 to 30\% (Yang et al., 2014; Valencia et al., 2015; Posey et al., 2015). Whereas groups that included only patients showing phenotypes involving the nervous system reported higher diagnostic yields. (Srivastava et al. 2014; Fogel, Satya \& Cohen 2016). Our results are comparable with these experiences and highlight the advantages of working as a personalized research group where phenotypic and genotypic information can 
be thoughtfully assessed in comparison with commercial diagnostic laboratories that only have access to focused, heterogeneous and less informative clinical phenotypic reports filled by the external ordering physician. Noteworthy, the ability to identify causing mutation in the patients assisted in our clinic significantly increased when preNGS and posNGS eras were compared. (Rodríguez-Quiroga a et al.).

Two cases are illustrative of common themes in medical genomics (Prada et al., 2014; Ansar, 2015; Taylan et al. 2016). A non-sense mutation in GRIK2 caused a more complex phenotype than it was previously recognized for this gene. This gene encodes a glutamate receptor and was previously reported once in members of a consanguineous family segregating intellectual disability (Motazacker et al. 2007). Our patient presented besides intellectual disability, epilepsy, dystonia and behavioral problems of the autism spectrum (Córdoba et a. 2015). Thus, we were able to extend the phenotypic spectrum associated with this gene. We emphasize the finding of a mutation in KCNA2 in a patient with early onset epilepsy and ataxia. This variant was identified after periodic reanalysis of previously classified as negative WES. Mutations in KCNA2 were recently recognized as the cause of epileptic encephalopathies and early onset ataxia (Syrbe et al. 2015). This information was unknown at the moment of the initial analysis but being available when this WES was reassessed led us to reinterpret this case. A preliminary report on this subject by Williams et al. showed the diagnostic yield of WES reanalysis. In a cohort of 346 cases reanalyzed, a definitive answer was identified in $11.2 \%(\mathrm{n}=39)$, a finding related to a possible/probable diagnosis was identified in $16.3 \%(\mathrm{n}=56)$ and a new candidate was reported in $23.1 \%(\mathrm{n}=80)$ (unpublished data E Williams). 
In summary, the use of WES in the field of neurogenetics proved to be an effective, cost- and time-saving approach for the molecular diagnosis of a very heterogeneous and complex group of patients. It reduced the long time that these patients must undergo before getting a diagnosis and ended odysseys of many years. WES results also impacted the medical management of these patients and optimized the genetic counseling for these families. Negative WES still remain a challenge, given the complexity in the interpretation of genomic data and the lack of a thorough knowledge of monogenic disorders. 


\section{REFERENCES}

Ansar M, Jan A, Santos-Cortez RL, Wang X, Suliman M, Acharya A, et. al. (2015) Expansion of the spectrum of ITGB6-related disorders to adolescent alopecia, dentogingival abnormalities and intellectual disability. Eur J Hum Genet. [Epub ahead of print]

Baulac S. (2014) Genetics advances in autosomal dominant focal epilepsies: focus on DEPDC5. Prog Brain Res.213:123-39. doi: 10.1016/B978-0-444-63326-2.00007-7.

Bettencourt C, López-Sendón JL, García-Caldentey J, Rizzu P, Bakker IM et al. (2014) Exome sequencing is a useful diagnostic tool for complicated forms of hereditary spastic paraplegia. Clin Genet. 85:154-158. doi: 10.1111/cge.12133

Carmichael N, Tsipis J, Windmueller G, Mandel L, Estrella E. (2014) "Is it Going to Hurt?": The Impact of the Diagnostic Odyssey on Children and Their Families. J Genet Couns. 325-335. doi: 10.1007/s10897-014-9773-9

Carsana A, Frisso G, Intrieri M, Tremolaterra MR, Savarese G, et. al. (2010) A 15year molecular analysis of DMD/BMD: genetic features in a large cohort. Front Biosci. 1;2:547-58.

Córdoba M, Rodriguez-Quiroga S, Gatto EM, Alurralde A, Kauffman MA. (2014) Ataxia Plus Myoclonus in a 23-year-old patient due to STUB1 mutation. Neurology.15(83(3)):287-8. doi: 10.1212/WNL.0000000000000600

Córdoba M, Rodriguez S, Gonzalez-Morón D, Medina N y Kauffman MA. (2015) Expanding the spectrum of Grik2 mutations: intellectual disability, behavioural disorder, epilepsy and dystonia. Clin Genet. 87:293-5. doi: 10.1111/cge.12423

Eymard-Pierre, E., Yamanaka, K., Haeussler, M., Kress, W., Gauthier-Barichard, F., et. al. (2006) Novel missense mutation in ALS2 gene results in infantile ascending hereditary spastic paralysis. Ann. Neurol. 59: 976-980.

Fogel BL, Lee H, Deignan JL, Strom SP, Kantarci S, et al. (2014) Exome Sequencing in the Clinical Diagnosis of Sporadic or Familial Cerebellar Ataxia. JAMA Neurol. 110. doi: 10.1001/jamaneurol.2014

Fogel BL, Satya-Murti S and Cohen BH. (2016) Clinical exome sequencing in neurologic disease. Neurol Clin Pract 6(2):164-176

Gilissen C, Hehir-Kwa JY, Thung DT, et al. (2014) Genome sequencing identifies major causes of severe intellectual disability. Nature. 511:344-347. doi: 10.1038/nature13394

Gootjes J, Schmohl F, Waterham HR, et al. (2004) Novel mutations in the PEX12 gene of patients with peroxisome biogenesis disorder. Eur J Hum Genet;12(2):115-20. 
Hynes, K., Tarpey, P., Dibbens, L. M., Bayly, M. A., Berkovic, S. F., et. al. (2010) Epilepsy and mental retardation limited to females with PCDH19 mutations can present de novo or in single generation families. J. Med. Genet. 47: 211-216. doi: 10.1136/jmg.2009.068817

Holt, I. J., Harding, A. E., Petty, R. K. H., Morgan-Hughes, J. A. (1990) A new mitochondrial disease associated with mitochondrial DNA heteroplasmy. Am. J. Hum. Genet. 46: 428-433.

Johansen Taber K a, Dickinson BD, Wilson M. (2014) The promise and challenges of next-generation genome sequencing for clinical care. JAMA Intern Med. 174:275-80. doi: 10.1001/jamainternmed.2013.12048

Kozarewa I, Turner DJ. (2011) Amplification-free library preparation for paired-end Illumina sequencing. Methods Mol Biol. 2011;733:257-66. doi: 10.1007/978-161779-089-8_18.

Lasa, A., Piccolo, F., de Diego, C., Jeanpierre, M., Colomer, J., et. al. (1998) Severe limb girdle muscular dystrophy in Spanish gypsies: further evidence for a founder mutation in the gamma-sarcoglycan gene. Europ. J. Hum. Genet. 6: 396-399.

Heng L (2013) Aligning sequence reads, clone sequences and assembly contigs with BWA-MEM. Preprint. https://arxiv.org/pdf/1303.3997v2.pdf

Margraf RL, Durtschi JD, Dames S, et al. (2011) Variant identification in multisample pools by illumina genome analyzer sequencing. J Biomol Tech. 22(2):74-84.

Mercimek-Mahmutoglu S, Patel J, Cordeiro D, Hewson S, Callen D, Donner EJ, et al. (2015) Diagnostic yield of genetic testing in epileptic encephalopathy in childhood. Epilepsia. 56(5):707-16. doi: 10.1111/epi.12954

Monroe GR, Frederix GW, Savelberg SM et al. (2016) of whole-exome sequencing and costs of the traditional diagnostic trajectory in children with intellectual disability. Genet Med. doi: 10.1038/gim.2015.200. [Epub ahead of print]

Motazacker MM, Rost BR, Hucho T et al. (2007) A defect in the ionotropic glutamate receptor 6 gene (GRIK2) is associated with autosomal recessive mental retardation. Am J Hum Genet: 81 (4): 792-798. DOI:10.1086/521275.

Nakamura, K., Kodera, H., Akita, T., Shiina, M., Kato, M. et. al. (2013) De novo mutations in GNAO1, encoding a G-alpha-o subunit of heterotrimeric G proteins, cause epileptic encephalopathy. Am. J. Hum. Genet. 93: 496-505. doi: 10.1016/j.ajhg.2013.07.014

O Pongs, N Kecskemethy, R Müller, et al. (1988) Shaker encodes a family of putative potassium channel proteins in the nervous system of Drosophila. EMBO J; 7(4): $1087-1096$.

Posey JE, Rosenfeld JA, James RA, Bainbridge M, Niu Z, Wang X, et. al. (2015) Molecular diagnostic experience of whole-exome sequencing in adult patients. Genet 
Med. Dec 3. [Epub ahead of print]

Prada CE1, Gonzaga-Jauregui C2, Tannenbaum R3, Penney S4, Lupski JR5, Hopkin RJ3, et. al. (2014) Clinical utility of whole-exome sequencing in rare diseases: Galactosialidosis. Eur J Med Genet. 57(7):339-44.

Richards CS, Bale S, Bellisimo DB, et. al. (2008) ACMG recommendations for standards for interpretation and reporting of sequence variations: Revisions 2007. Genet Med. 2010(4):294-300. doi: 10.1097/GIM.0b013e31816b5cae.

Richards CS, Azis N, Bale S, et. al. (2015) Standards and guidelines for the interpretation of sequence variants: a joint consensus recommendation of the American College of Medical Genetics and Genomics and the Association for Molecular Pathology. Genet Med. 17(5):405-24.

Riant F, Ducros A, Ploton C et al. (2010) De novo mutations in ATP1A2 and CANA1A are frequent in early-onset sporadic hemiplegic migraine. Neurology; 75(11):967-72.

Rodríguez-Quiroga SA, Cordoba M, González-Morón D, et al. Neurogenetics in Argentina: diagnostic yield in a personalized research based clinic.(2015) Genet Res (Camb). 2015;97:e10.

Rodríguez-Quiroga SA, Rosales J, Arakaki T, Cordoba M, González-Morón D, Medina N, et. al. (2015) Timely diagnosis of Wilson's disease using whole exome sequencing. Parkinsonism Relat Disord. 21(11):1375-7. doi: 10.1016/j.parkreldis.2015.09.031.

Shi CH, Schisler JC, Rubel CE, et al. (2014) Ataxia and hypogonadism cause by the loss of ubiquitin ligase activity of the $U$ box protein CHIP. Hum Mol Genet;23(4):1013-24.

Shimazaki, H., Takiyama, Y., Sakoe, K., Ikeguchi, K., Niijima, K., et. al. (2002) Early-onset ataxia with ocular motor apraxia and hypoalbuminemia: the aprataxin gene mutations. Neurology 59: 590-595

Srivastava S, Cohen JS, Vernon H, et al. (2014) Clinical whole exome sequencing in child neurology practice. Ann Neurol. 76(4):473-83. doi: 10.1002/ana.24251.

Stevanin, G., Santorelli, F. M., Azzedine, H., Coutinho, P., Chomilier, J., et. al. (2007) Mutations in SPG11, encoding spatacsin, are a major cause of spastic paraplegia with thin corpus callosum. Nature Genet. 39: 366-372.

Syrbe S, Hedrich UB, Riesch E, Djémié T, Müller S, et. al. (2015) De novo loss- or gain-of-function mutations in KCNA2 cause epileptic encephalopathy. Nat Genet. 47(4):393-9. doi: 10.1038/ng.3239.

Takeshita Y, Shimizu N, Yamaguchi Y, et al. (2002) Two families with Wilson disease in wich siblings showed different phenotypes. J Hum Genet;47(10):543-7. 
Taylan F, Costantini A, Coles N, Pekkinen M, Héon E, Şıklar Z et. al. (2016) Spondyloocular Syndrome - Novel Mutations in XYLT2 Gene and Expansion of the Phenotypic Spectrum. J Bone Miner Res. [Epub ahead of print]

Valencia CA, Husami A, Holle J, Johnson JA, Qian Y, Mathur A, et. al. (2015) Clinical Impact and Cost-Effectiveness of Whole Exome Sequencing as a Diagnostic Tool: A Pediatric Center's Experience. Front Pediatr. Aug 3;3:67

Van der Auwera GA, Carneiro MO, Hartl C, (2013) From FastQ data to high confidence variant calls: the Genome Analysis Toolkit best practices pipeline.Curr Protoc Bioinformatics. 43:11.10.1-33. doi: 10.1002/0471250953.bi1110s43.

Wang K, Li M, Hakonarson H. (2010) ANNOVAR: functional annotation of genetic variants from high-throughput sequencing data. Nucleic Acids Res.38(16):e164. doi: 10.1093/nar/gkq603.

Wolf, N. I., Vanderver, A., van Spaendonk, R. M. L., Schiffmann, R., Brais, B., et. al (2014) Clinical spectrum of 4H leukodystrophy caused by POLR3A and POLR3B mutations. Neurology 83: 1898-1905. doi: 10.1212/WNL.0000000000001002

Wright FA, Lu JP, Sliter DA, et al. (2015). A Point Mutation in the Ubiquitin Ligase RNF170 That Causes Autosomal Dominant Sensory Ataxia Destabilizes the Protein and Impairs Inositol 1,4,5-Trisphosphate Receptor-mediated Ca2+ Signaling. J Biol Chem. 290(22):13948-57. doi: 10.1074/jbc.M115.655043

Xie G1, Harrison J, Clapcote SJ et al. A new Kv1.2 channelopathy underlying cerebellar ataxia. J Biol Chem. 285(42):32160-73. doi: 10.1074/jbc.M110.153676.

Yang Y, Muzny DM, Xia F, et al. (2014) Molecular findings among patients referred for clinical whole-exome sequencing. JAMA;312(18):1870-1879. 